\title{
Narratives of the Provenance of Art and Antiquities on the Market and the Reality of Origins at the Source
}

\begin{abstract}
This essay presents the findings of the International Conference on Handling of Cultural Goods and Financing of Political Violence and introduces provenance research that examines the market in Europe for antiquities from Asia and the market in North America for antiquities from Europe. It summarises findings, such as the involvement of violent political organisations, transnational organised criminals and politically-exposed persons (PEPs) in illicit trafficking of cultural objects. It also highlights some foundations for progress, such as enhanced traceability and due diligence in the art market, plus action and cooperation to respond to illicit flows as regional problems.
\end{abstract}

Amidst the outbreak, continuation or intensification of conflicts and other crises in North Africa, West Asia, Eastern Europe and beyond, not only cultural property but also cultural property crime is increasingly being exploited for political capital. Not only objects, structures and sites but also treatments of those pieces of heritage are increasingly being deployed in propaganda.

There are law enforcement agents and cultural heritage workers as well as antiquities trade representatives who downplay or deny even the existence of organised cultural property crime. At the same time, there are law enforcement agents and cultural heritage workers as well as antiquities trade representatives, plus politicians and NGOs and journalists, who present evidence that has been misinterpreted, manipulated or even fabricated.

Nevertheless, there is a counterbalancing body of work by professional experts and concerned citizens around the world. This includes research under the Heritage Experience Initiative (HEI) of the University of Oslo and investigations by participants in the International Conference on Handling of Cultural Goods and Financing of Political Violence at the Norwegian Institute in Rome. 
As a product of this work, there is deepening and expanding documentation of the financing and incentivisation of political violence by states, paramilitaries, militias and terrorists. There are cases from Latin America to Asia, from Europe to Africa. Some occurred more than a century ago, while others are ongoing. Complementarily, there is deepening and expanding documentation of the participation of organised crime groups, organised crime networks and politically-exposed persons in illicit trafficking of cultural goods and moneylaundering with cultural goods.

At the time of writing, there was renewed discussion of the financing of the war over the Falkland Islands by the dictatorship in Argentina, through the burglary of its own National Museum of Fine Arts and the sale or bartering of the stolen cultural goods for military equipment from an arms dealer in Taiwan. ${ }^{1}$ Likewise, it had previously been reported that the junta had made untraceable payment-in-kind to the perpetrators of "disappearances" (assassinations), in the form of permission to steal art and artefacts. ${ }^{2}$ Such cases emphasise the harm that persists while cultural property protection and policing are minimal, disjointed and/or politicised.

\section{Handling of Cultural Goods and Financing of Political Violence}

Delayed and reformatted due to the Covid-19 pandemic and despite the best efforts of the administrators, Anne Nicolaysen and Mona Johansen, on 22-23 October 2020, the Norwegian Institute in Rome hosted an online conference of experts from the fields of archaeology, art history, criminology, non-governmental work, international governance and law enforcement. They discussed looting, theft, forgery and trafficking of cultural property from North Africa, West Asia and Eastern Europe; handling of illicit goods in Western Europe and North America; and conflict financing, which encompassed everything from terrorist funding to regime enrichment.

The meeting compiled evidence of extraction of cultural assets during conflict and crisis; documented the involvement of people with legal and illegal political power; explored how criminals operate, and with whom they cooperate, from source to market, including in conflict economies and insecure states; assessed risks for societies where markets consume art and antiquities without due diligence and online markets operate without effective governance; and considered which indicators to monitor, which offences to target and how. It was a private meeting, to enable free discussion of sensitive data. So, some information cannot be recounted in detail here and other information is in the process of being published elsewhere. Nonetheless, some broad points can be made.

The present author provided an introduction to a Multiplicity of Crimes by a Network of Networks. It revealed overlaps between the business and politics of communities of treasurehunters and communities of violent radicals, such as those in Turkey and Ukraine. It also outlined interconnections through cultural property crime between violent political organisations, transnational organised criminals and politically-exposed persons (PEPs) that span zones of conflict and crisis, such as chains that link actors in Syria and Ukraine, and that reach dealers and collectors in Western markets.

\footnotetext{
${ }^{1}$ Di Liscia 2021; see also Subiela Salvo 2020.

${ }^{2}$ Schávelzon 2002.
} 


\section{Conflict zones}

A member of the ISIL / Al-Qaida - Taliban Monitoring Team of the United Nations Security Council, Angelo Felicetti, presented the team's ongoing tracking of Terrorist Financing through Antiquities Trafficking, including fundraising through online trading of cultural objects and the bureaucratisation of racketeering by the Islamic State in Iraq and Syria. ${ }^{3}$ An honorary researcher at Birkbeck University, Adnan Almohamad, detailed Terrorist Financing in Syria and other aspects of the political economy of destruction and looting in and around Manbij. ${ }^{4}$

The scale and complexity of the intersection between cultural property crime and political violence was highlighted by a member of Mwatana for Human Rights, Eyad Dammaj, who presented the Degradation of History: Violations Committed by the Warring Parties against Yemen's Cultural Property. ${ }^{5}$ Mwatana's report demonstrated the range of violent actors in illicit trafficking and the range of their actions in this one, grossly neglected conflict.

For instance, solely with regard to looting and theft that directly involved violent political organisations, the archaeological site of al Sawda in al Jawf was militarised by governmentaligned resistance forces and looted. The Shree Hingraj Mataji Mandir of the Hindu minority community in Aden was severely damaged by Ansar al-Sharia, who then facilitated the pillaging of that temple by civilians. The Military Museum in Aden was militarised and pillaged by Ansar Allah. Salh Castle in Taiz was militarised and pillaged by Ansar Allah. The National Museum of Archaeology at al-Oradi Castle in Taiz was militarised by Ansar Allah, then pillaged by the attacking Abu Abbas Brigades. The historic building of al-Qefel in Sa'ada was militarised and pillaged by Ansar Allah. And the Church of Saint Joseph in Aden was subjected to iconoclasm and pillaged by al-Qaida. ${ }^{6}$

The co-director of the Antiquities Trafficking and Heritage Anthropology Research Project, Katie Paul, showed the involvement of members of violent political organisations in online trafficking everywhere from West Asia to Eastern Europe, among the Middlemen of Social Media: Terrorist and Transnational Criminal Financing through Online Trafficking. ${ }^{7}$ Paul showed that traffickers could profit by selling antiquities and forgeries through social networks and other online platforms; by brokering access to sites and/or providing looting/theft-to-order; by taxing sales within their communities; and by hosting others' adverts alongside their own. Moreover, Paul showed that online platforms from Facebook to YouTube could profit from those transactions and adverts as well.

\section{Crisis zones}

A doctoral researcher at the University of Copenhagen and the National Museum of Denmark, Marie Elisabeth Berg Christensen, discussed Looting from Archeological Sites in Countries Neighboring Areas of Armed Conflict: the Case of Umm el-Jimal in Northern Jor-

\footnotetext{
${ }^{3}$ E.g. UNSCASSMT 2021.

${ }^{4}$ E.g. Almohamad 2021.

${ }^{5}$ E.g. Mwatana for Human Rights 2018.

${ }^{6}$ Mwatana for Human Rights 2018.

${ }^{7}$ E.g. Al-Azm, Paul with Graham 2019; Al-Azm, Paul 2018; Al-Azm, Paul 2020.
} 
dan. ${ }^{8}$ Christensen observed that peripheral crisis zones typically suffer long-standing problems like those of central conflict zones, plus suffer 'spillover' problems from those conflict zones, such as political instability and economic instability and so increased looting and trafficking, yet remain neglected.

A doctoral researcher at Istanbul University, Mustafa Ergül, added further detail to the image of criminal activity in crisis zones, when he analysed the Trafficking of Forged Artworks in and through Turkey: the Turkish Picassos. ${ }^{9}$ Ergül showed examples of organised cultural property crime; poly-trafficking of authentic and fake cultural goods with other commodities like narcotics; and counterfeiting and forgery of art and antiquities of minority communities.

The Head of the Anti-Trafficking Department of the Ministry of Culture and Tourism in Turkey, Zeynep Boz (who participated in the discussion), observed another intersection of problems across troubled regions: profit-driven criminals from conflict zones sometimes gain residency or citizenship in neighbouring countries. When such criminals are handling material from ancient cultures that span modern borders, it may be difficult to determine if they are engaging in trafficking from the conflict zone or looting in the neighbouring country. Consequently, it may be difficult to analyse and combat the activity most effectively.

Exemplifying the flow of stolen cultural goods from victimised societies to unscrupulous consumers, a doctoral researcher at the École Pratique des Hautes Études (EPHE), Morgan Belzic, traced Trafficking of Antiquities from Libya to Europe ${ }^{10}$ Curators on the Circulating Artefacts (CircArt) Project of the British Museum, Marcel Marée and Maxence Garde, traced the Trade in Antiquities from Egypt and Sudan to Western markets. These cases demonstrated that activity cannot be addressed solely as a national problem in, for instance, Sudan, Egypt or Libya; it also needs to be addressed as a regional problem in Sudan, Egypt and Libya.

One senior researcher at the Institute of Archaeology of the National Academy of Sciences of Ukraine, Yakov Gershkovich, discussed Embezzlement and Destruction of the Archaeological Heritage in Ukraine: Real Scale and Catastrophic Results. ${ }^{11}$ Another, Serhii Telizhenko, discussed Looting and Destruction during the Post-Revolutionary Crisis in Ukraine. ${ }^{12}$ The losses of archaeological goods, in a region that was already a neglected crisis zone and is now another neglected conflict zone, truly constituted a 'catastrophe'.

\section{Criminal markets}

A police expert at the École Nationale Supérieure de la Police in France, Corinne Chartrelle, discussed Organised Cultural Property Crime in France. The contact point for cultural property crime in the Federal Judicial Police of Belgium, Lucas Verhaegen (who spoke in a personal capacity), discussed Organised Cultural Property Crime in Belgium. And one of the authors in this volume, a postdoctoral researcher at the University of Agder, Josephine Munch Rasmussen, discussed the Market for Antiquities in Norway. Amongst other things,

\footnotetext{
${ }^{8}$ E.g. Christensen 2017; Christensen 2018.

${ }^{9}$ E.g. Ergül 2018.

${ }^{10}$ E.g. Belzic 2017; Belzic 2019; Belzic, Menozzi, Sharif, Mei, Di Valerio 2020.

${ }^{11}$ E.g. Gershkovich 2005; Gershkovich 2011.

${ }^{12}$ E.g. Telizhenko 2019.
} 
Rasmussen showed not only how cultural objects had been looted and stolen or forged in vulnerable societies such as Afghanistan, Pakistan, Iraq, Jordan, Palestine and Israel and trafficked to collectors in secure societies such as Norway, but also how suspect objects and even demonstrably-criminally-sourced objects in Western markets had been permitted to be reexported.

The fight against the illicit trafficking of cultural goods and the financing of political violence with cultural goods

Thanks to the inordinate patience of the papers' authors, the present author's co-editor, Mattia Biffis, the librarian, Manuela Michelloni and the director, Christopher Prescott, the following papers are two of the works that flow from the conference. Arstein Justnes is a professor in the Department of Religion, Philosophy and History at the University of Agder, where he is the Principal Investigator of the Lying Pen of Scribes: Manuscript Forgeries, Digital Imaging, and Critical Provenance Research. ${ }^{13}$ Josephine Munch Rasmussen is a postdoctoral research fellow there, where she is undertaking a project on Academic Consumption of Ancient Manuscripts: Dealing with Provenance. ${ }^{14}$ Here, they explore Tales of Saviours and Iconoclasts: the Provenance of "the Dead Sea Scrolls of Buddhism" in the Schøyen Collection, through which they reveal the interdependence of the scholars who publish manuscripts and the collectors who consume them, plus the harm that is done to historical knowledge and thereby to contemporary societies.

A postdoctoral research fellow at the Aarhus Institute of Advanced Studies, Christos Tsirogiannis (who was scheduled to speak at the conference as well, but was unavailable on the rescheduled date) is undertaking a project on Monitoring the Trade in Illicit Antiquities. ${ }^{15}$ Here, he considers the Antiquities Market We Deserve: "Royal-Athena Galleries" (19422020), through which, he documents persistent knowing handling of suspect objects by some of the most prominent actors in the international market. He also reveals peculiarities in academic research, law enforcement, cultural diplomacy and media coverage that obscure and undermine the work of provenance researchers - who are very often unpaid workers - and thereby the very flow of intelligence that enables academic research, law enforcement, cultural diplomacy and public education.

As these papers lay bare, there remains a dire need for maintenance of documentation and observation of due diligence by market actors. Yet, while the spread of consumer ethics and commercial ethics will significantly reduce harm to victimised societies and compromised markets, it will not be enough on its own. Ethics alone will never completely exclude the emergence of bad faith actors. It can never completely protect good faith purchasers among collectors and dealers from infiltration by bad faith actors in the supply chain nor cultural resources from appropriation by those bad faith actors.

\footnotetext{
${ }^{13}$ E.g. Justnes 2015; Justnes 2017; Justnes 2019a; Justnes 2019b; Justnes, Elgvin 2018; Justnes, Rasmussen 2020; Justnes, Rasmussen 2021.

${ }^{14}$ E.g. Gundersen, Rasmussen, Lie 2016; Justnes, Rasmussen 2020; Justnes, Rasmussen 2021; Prescott, Rasmussen 2020; Rasmussen 2014; Rasmussen 2020; Rasmussen, Prescott 2011.

15 E.g. Gill, Tsirogiannis 2011; Tsirogiannis 2013; Tsirogiannis 2015; Tsirogiannis 2016a; Tsirogiannis 2016b; Tsirogiannis 2019; Tsirogiannis, Gill 2014.
} 
As the conference demonstrated, in order for the benefits of this work to be consolidated and sustained, much else needs to be done. With regard to everyday law enforcement, states need to criminalise the import of cultural goods into one country that have been illegally exported from another; to harmonise the requirements for traceability of goods on the market; and to ensure the translatability of offences for international law enforcement. To enforce sector-specific law effectively, there is a need for training and capacity-building in general and for specialised agents/units in police/customs in particular, including ones that specialise in the monitoring of online markets. Still, there are also opportunities to use existing laws, such as ones that address financial crime, to prosecute certain common acts in cultural property crime, such as misrepresentation of goods.

With regard to intelligence-led policing, there is a need for collection and sharing of data by states, as well as procedures and systems to organise those activities; gathering of intelligence, to guide the gathering of evidence; and establishment of a market monitoring mechanism, to generate systematic intelligence and evidence, as well as to encourage ethical conduct.

There are already complementary efforts to control the market, which include monitoring by archaeologists, art historians and criminologists in close collaboration with specialist law enforcement agents - and these are already having success. With long-term security and capacity for projects such as Circulating Artefacts, these efforts could underpin a decisive shift in cultural property policing, from recovery of stolen assets, to disruption of illicit flows of cultural goods out of - and finances into - zones of crisis and conflict.

Samuel Andrew Hardy

University of Oslo

The Norwegian Institute in Rome s.a.hardy@roma.uio.no 


\section{BIBLIOGRAPHY}

Al-Azm A., Paul K.A. with Graham S. 2019: Facebook's black market in antiquities: Trafficking, terrorism, and war crimes, Washington, D.C., Antiquities Trafficking and Heritage Anthropology Research (ATHAR) Project.

Al-Azm A., Paul K.A. 2018: "The Middle East's other Facebook revolution: Antiquities trafficking in the digital age", World Politics Review, 14 August, https://www.worldpoliticsreview.com/articles/25532/ the-middle-east-s-other-facebook-revolutionantiquities-trafficking-in-the-digital-age.

Al-Azm A., Paul K.A. 2020: “Facebook's flawed plan to end antiquities trafficking: Evidence of war crimes must be preserved, not destroyed", Foreign Affairs, 1 July, https://www.foreignaffairs.com/articles/middle-east/2020-07-01/facebooks-flawed-plan-end-antiquities-trafficking.

Almohamad A. 2021: "The destruction and looting of cultural heritage sites by ISIS in Syria: The case of Manbij and its countryside", International Journal of Cultural Property, 1-40, https://doi.org/10.1017/S0940739121000114.

Belzic M. 2017: “Les sculptures funéraires de Cyrénaïque sur le marché de l'art [funerary sculp-tures from Cyrenaica on the art market]", Libyan Stu-dies, 48, 105-116.

Belzic M. 2019: "La Belle Endormie: Une divinité funéraire de Cyrénaïque saisie à New York [Sleeping Beauty: A funerary deity from Cyrenaica, seized in New York]", Quaderni di Archeologia della Libya 22, 25-44

Belzic M., Menozzi O., Sharif A.S., Mei O., Di Valerio E. 2020: "Phero semeros e i contesti spezzati: Nuovi schemata iconografici dalla necro-poli di Cirene: Dal traffico illecito alla ricostruzione dei contesti [Phero semeros and broken contexts: New iconographic schemata from the necropolis of Cyrene: From illicit trafficking to the reconstruction of contexts]", Libya Antiqua 13, 159-204.

Christensen M.E.B. 2017: "Krig og kulturarv [war and cultural heritage]", Weekendavisen 15 September, 12.

Christensen M.E. 2018: Den transnationale фdelaggelse af kulturvardier som folge af vabnet konflikt - med casestudier af Jerash og Umm el-Jimal i det nordlige Jordan [the transnational destruction of cultural assets as a result of armed conflict - with case studies of Jerash and Umm el-Jimal in northern
Jordan], Copenhagen, Det Kongelige Akademi Arkitektur, Design, Konservering (unpublished MSc thesis).

Di Liscia V. 2021: “Argentina's military government may have stolen from its own museum to fund Falklands War", Hyperallergic 3 May, https://hyperallergic.com/641448/argentinas-military-government-may-have-stolen-from-its-own-museum-tofund-falklands-war/.

Ergül M. 2018: The Turkish Picassos, https://www.theturkishpicassos.com/.

Gershkovich Ya.P. 2005: “Хранителі нелегальних старожитностей в Україні [Keepers of illegal antiquities in Ukraine]", Археологія vol. 3, 91-97.

Gershkovich Ya.P. 2011: "The All-Ukrainian Public Association of Archaeologists: Its purposes and plan of actions", The European Archaeologist 35, 14-16.

Giglio M., al-Awad M. 2015: "Inside the underground trade to sell off Syria's history", BuzzFeed News, 30 July, http://www.buzzfeed.com/mikegiglio/the-tradein-stolen-syrian-artifacts.

Gill D.W.J., Tsirogiannis C. 2011: "Polaroids from the Medici dossier: Continued sightings on the market", Journal of Art Crime 5, 27-33.

Gundersen J., Rasmussen J.M., Lie R.O. 2016: "Private metal detecting and archaeology in Nor-way", Open Archaeology 2 (1), 160-170.

Justnes Å. 2015: "Gabriels åpenbaring (Hazon Gabriel) - en moderne forfalskning? [Gabriel's Revelation (Hazon Gabriel) - a modern forgery?]", Teologisk Tidsskrift 4 (2), 120-133.

Justnes Å. 2017: "Forfalskninger av dødehavsruller. Om mer enn 70 nye fragmenter - og historien om ett av dem (DSS F.154; 5 Mos 27,4-6) [Counterfeits of Dead Sea Scrolls. About more than 70 new fragments - and the story of one of them (DSS F.154; Deut. 27: 4-6)]", Teologisk Tidsskrift 6 (1), 70-83.

Justnes A. 2019a: "Fake fragments, flexible provenances: Eight Aramaic 'Dead Sea Scrolls' from the $21^{\text {st }}$ Century”, in M. Bundvad, K. Siegismund (eds.), Vision, narrative, and wisdom in the Aramaic texts from Qumran, Leiden, 242-271.

Justnes ̊. 2019b: De falske fragmentene og forskerne som gjorde dem til dodehavsruller [the fake fragments and the scientists who turned them into Dead Sea Scrolls], Oslo.

Justnes Å., Elgvin T. 2018: “A private part of Enoch: A forged fragment of 1 Enoch 8:4-9:3", in J.H. El- 
lens, I.W. Oliver, J. von Ehrenkrook, J. Waddell, J.M. Zurawski (eds.), Wisdom poured out like water: Studies on Jewish and Christian Antiquity in honor of Gabriele Boccaccini, Berlin, 195-203.

Justnes A., Rasmussen J.M. 2020: "Hazon Gabriel: A display of negligence", Bulletin of the American Schools of Oriental Research (BASOR), 384 (1), 6976.

Justnes Å., Rasmussen J.M. 2021: "More dubious Dead Sea Scrolls: Four pre-2002 fragments in the Schøyen Collection", Dead Sea Discoveries 28 (1), 20-37.

Mwatana for Human Rights. 2018: The degradation of history: Violations committed by the warring parties against Yemen's cultural property, Sana'a, Mwatana for Human Rights.

Prescott C., Rasmussen J.M. 2020: "Exploring the 'cozy cabal of academics, dealers and collectors' through the Schøyen Collection". Heritage 3 (1), 6891, http://dx.doi.org/10.3390/heritage3010005.

Rasmussen J.M. 2014: "Securing cultural heritage objects and fencing stolen goods? A case study on museums and metal detecting in Norway", Norwegian Archaeological Review 47 (1), 83-107.

Rasmussen J.M. 2020: "Regulating the import and export of cultural objects in Norway. Background and Challenges", in R. Bonnie (ed.), Working with cultural objects and manuscripts: Provenance, legality, and responsible stewardship, Helsinki, 94-106.

Rasmussen J.M., Prescott C. 2011: "Implementation, complications and lack of education: Some reflections on the advantages of knowledge exchange", in L. Ramskjaer, A. Nyhamar, A. Chabiera, M. Aniszewski (eds.), Stop heritage crime: Good practices and recommendations, Warsaw, 117-120.

Schávelzon D. 2002: "What's going on around the corner? Illegal trade of art and antiquities in Argentina", in N. Brodie, K.W. Tubb (eds.), Illicit antiquities: The theft of culture and the extinction of archaeology, London, 228-234.

Subiela Salvo I. 2020: "Robo al museo: El millonario robo de la dictadura argentina [Robbery at the museum: The millionaire robbery of Argentina's dictatorship]", Gatopardo, 17 December, https://gatopardo.com/reportajes/el-millonario-robo-de-la-dictadura-argentina-al-museo-nacional-de-bellas-artes-debuenos-aires/.
Telizhenko S. 2019: “Ситуація 3 археологічною спадщиною в зоні проведення бойових дій (Луганська область) [the situation of archaeological heritage in the area of hostilities (Lugansk region)]", Seminar on Archaeology in Occupied Territories and in Zones of Armed Conflict [Археологія на окупованих територіях та у зонах збройних конфліктів], Kyiv, Ukraine, 16 May [YouTube, 6 June], https://www.youtube.com/watch?v=zlU4rvJfgTs.

Tsirogiannis C. 2013: "Something is confidential in the State of Christie's", Journal of Art Crime 9, 3-19.

Tsirigiannis C. 2015: "Mapping the supply: Usual suspects and identified antiquities in 'reputable' auction houses in 2013", Cuadernos de Prehistoria y Arqueología 25, 107-144.

Tsirogiannis C. 2016a: "False closure? Known unknowns in repatriated antiquities cases", International Journal of Cultural Property 23, 407-431.

Tsirogiannis C. 2016b: "Uncovering the hidden routes: Algorithms for identifying paths and missing links in trade networks", in T. Brughmans, A. Collar, F. Coward (eds.), The connected past: Challenges to network studies in archaeology and history, Oxford, 103-120.

Tsirogiannis C. 2019: "Illicit antiquities in American museums: Diversity in ethical standards", in D. Chappell, S. Hufnagel (eds.), Handbook of Art Crime, Palgrave Macmillan, 815-838.

Tsirogiannis C., Gill D. 2014: “'A fracture in time': A cup attributed to the Euaion Painter from the Bothmer Collection", International Journal of Cultural Property 21, 465-480.

UNSCASSMT (United Nations Security Council Analytical Support and Monitoring Team). 2021: Twenty-seventh report of the Analytical Support and Sanctions Monitoring Team submitted pur-suant to resolution 2368 (2017) concerning ISIL (Da'esh), Al-Qaida and associated individuals and entities [S/2021/68, 3 February 2021], New York 